Conclusion: Colchicine $1 \mathrm{mg}$ daily for 12 weeks was not effective in improving pain, tender and swollen joint count or grip strength in symptomatic hand osteoarthritis patients. This study does not support colchicine for treatment of symptoms of hand osteoarthritis.

References:

[1] Leung, YY, Hui, LLY, Kraus, VB 2015. Colchicine-Update on mechanisms of action and therapeutic uses. Seminars in Arthritis and Rheumatism; 45: 341-350.

[2] Altman, R, Alarcon, G, Appelrouth, D et al, 1990. American College of Rheumatology criteria for the classification and reporting of osteoarthritis of the hand. Arthritis Rheumatology; 33(11): 1601-10.

[3] Liu GF, Lu K, Mogg R, et al. 2009. Should baseline be a covariate or dependent variable in analyses of change from baseline in clinical trials? Stat Med; 28: 2509-30.

Characters from table content including title and footnotes: 465

Disclosure of Interests: None declared

DOI: 10.1136/annrheumdis-2020-eular.4040

\section{FRI0400 EFFICACY AND SAFETY OF AN INTRA-ARTICULAR INJECTION OF JTA-004, A NOVEL ENHANCED PROTEIN SOLUTION, IN KNEE OSTEOARTHRITIS PAIN: A RANDOMISED, DOUBLE-BLIND CONTROLLED PHASE II/III STUDY}

M. Bettonville ${ }^{1}$, M. Leon ${ }^{2}$, J. Margaux ${ }^{3}$, D. Urbin-Choffray ${ }^{4}$, E. Theunissen ${ }^{5}$, T. Besse-Hammer ${ }^{6}$, Y. Fortems ${ }^{7}$, S. Verlinden ${ }^{8}$, O. Godeaux ${ }^{1}$, A.

S. Delmarcelle ${ }^{1}$, J. F. Kaux ${ }^{9} .{ }^{1}$ Bone Therapeutics S.A., Gosselies, Belgium; ${ }^{2} \mathrm{CHU}$ Ambroise Paré, Mons, Belgium; ${ }^{3}$ Hopital Erasme, Bruxelles, Belgium; ${ }^{4} \mathrm{CHR}$ de la Citadelle, Liège, Belgium; ${ }^{5}$ Clinique Saint-Pierre Ottignies, Ottignies, Belgium; ${ }^{6} \mathrm{CHU}$ Brugmann, Bruxelles, Belgium; ${ }^{7} \mathrm{AZ}$ Sint-Jozef Malle, Malle, Belgium; ${ }^{8} \mathrm{CHR}$ Haute Senne, Soignies, Belgium; ${ }^{9} \mathrm{CHU}$ Liège, Liège, Belgium

Background: Osteoarthritis (OA) is a degenerative, chronic, and progressive joint disease. It is associated with chronic pain, joint function impairments and disabilities, causing a poorer quality of life with physical and/or mental co-morbidity. Along with population ageing and increasing obesity, the incidence of OA is rising and there is an urgent need for new treatment options.

Objectives: JTA-004 is a novel protein solution in development for the treatment of knee OA pain. Supplemented with hyaluronic acid and clonidine, it is designed to provide a fast-acting and long-lasting pain relief. To evaluate efficacy and safety and to select the most effective formulation, single intra-articular administration of 3 JTA-004 formulations were tested and compared to Hylan G-F 20 during a 6-month period.

Methods: In this prospective, multicentre, double-blind phase II/III trial (NCT02740231), eligible participants were 50-79-year-old men and women with primary knee OA classified with Kellgren-Lawrence grade II or III and a body mass index (BMI) under 35. 164 patients were randomly assigned to one of the three JTA-004 formulations or the reference treatment (Hylan G-F 20) in a 1:1:1:1 ratio. The three JTA-004 formulations differed in their clonidine concentration (50 or $100 \mu \mathrm{g} / \mathrm{ml}$ ) and/or their volume of injection (2 or $4 \mathrm{ml}$ ) (Table 1). Patients were evaluated using Western Ontario McMaster Universities (WOMAC ${ }^{\circledR}$ ) scores and Short-Form health survey (SF-12). The primary efficacy endpoint was the change from baseline at 6 months in WOMAC ${ }^{\circledR}$ VA3.1 Pain Subscale. Safety was assessed by monitoring and reporting vital signs, physical examination, adverse events and concomitant medications throughout the study.
Table 1. Description of the three JTA-004 formulations administered

\begin{tabular}{|c|c|c|c|c|c|c|c|}
\hline $\begin{array}{l}\text { JTA-004 } \\
\text { formulation }\end{array}$ & $\begin{array}{l}\text { Plasma protein } \\
\text { solution }\end{array}$ & & Clonidine & & $\mathrm{HA}$ & & $\begin{array}{c}\text { Volume } \\
\text { of }\end{array}$ \\
\hline & Concentration & Amount & Concentration & Amount & Concentration & Amount & injection \\
\hline JTA-100/2 & $1.02 \mathrm{~g} / \mathrm{ml}$ & $2.04 \mathrm{~g}$ & $50 \mu \mathrm{g} / \mathrm{ml}$ & $100 \mu \mathrm{g}$ & $10 \mathrm{mg} / \mathrm{ml}$ & $20 \mathrm{mg}$ & $2 \mathrm{ml}$ \\
\hline JTA-200/2 & $1.02 \mathrm{~g} / \mathrm{ml}$ & $2.04 \mathrm{~g}$ & $100 \mu \mathrm{g} / \mathrm{ml}$ & $200 \mu \mathrm{g}$ & $10 \mathrm{mg} / \mathrm{ml}$ & $20 \mathrm{mg}$ & $2 \mathrm{ml}$ \\
\hline JTA-200/4 & $1.02 \mathrm{~g} / \mathrm{ml}$ & $4.08 \mathrm{~g}$ & $50 \mu \mathrm{g} / \mathrm{ml}$ & $200 \mu \mathrm{g}$ & $10 \mathrm{mg} / \mathrm{ml}$ & $40 \mathrm{mg}$ & $4 \mathrm{ml}$ \\
\hline
\end{tabular}

Results: At 6 months, patients in the three JTA-004 groups showed a better improvement in pain compared to patients in the reference group. The betweengroup difference (between each JTA-004 test group and reference group) in adjusted (adapted to difference in baseline values) mean change in WOMAC ${ }^{\circledR}$ Pain Subscale Score from baseline ranged between $-9.49 \mathrm{~mm}$ and $-11.63 \mathrm{~mm}$ at 6 months post-injection. Statistical superiority of each JTA-004 formulation over Hylan G-F 20 was however not demonstrated ( $p$-value between 0.052 and 0.141) (Figure 1, JTA 200/2, 100/2 and 200/4). As the three JTA-004 formulations had a similar efficacy in terms of pain reduction, a post hoc analysis was subsequently performed between the pooled JTA-004-treated patients and the reference group. This analysis showed a $26.1 \pm 2.4$ (adjusted mean \pm SE) $\mathrm{mm}$ improvement in pain in the pooled JTA-004 group vs. $15.6 \pm 4.1 \mathrm{~mm}$ in the reference group at 6 months, demonstrating a statistically significant superiority of JTA-004 over the reference (between-group difference $=-10.57 ; p=0.030$ ) (Figure 1, pooled JTA).

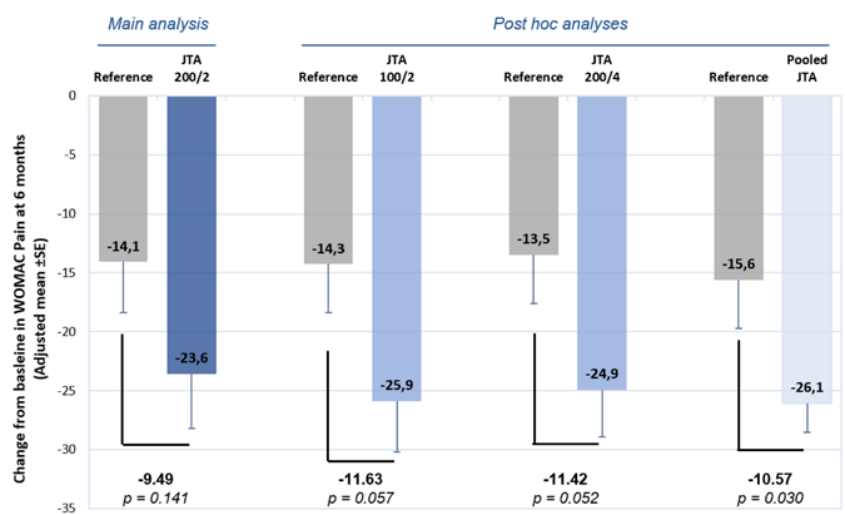

Figure 1. Main and post hoc analyses.

All JTA-004 formulations were shown to be well tolerated and had a clinically acceptable safety profile. There was a trend for fewer treatment-related events in the JTA-100/2 group, notably no cases of post-injection mild and transient hypotension.

Conclusion: This study provides a first evidence of efficacy and safety of JTA004 in the treatment of knee OA pain.

Disclosure of Interests: Marie Bettonville Employee of: Bone Therapeutics, Marc Leon: None declared, Joëlle Margaux: None declared, Didier Urbin-Choffray: None declared, Emilie Theunissen: None declared, Tatiana Besse-Hammer: None declared, Yves Fortems: None declared, Séverine Verlinden: None declared, Olivier Godeaux Consultant of: Bone Therapeutics, Anne-Sophie Delmarcelle Employee of: Bone Therapeutics, Jean-François Kaux Consultant of: Bone Therapeutics

DOI: 10.1136/annrheumdis-2020-eular.1961 